the idea that there is anything or could be anything other than greed involved in capitalism. It lies exposed for what it is. The market has no heart. It does not-it cannot-care.

Whoever was responsible for the attacks should be brought to justice for these appalling crimes. While the inferno of racial and religious hatred that has followed is at least as appalling, other voices are beginning to be heard. The notion of the world being a village community has never been more explicit than on 11 September. Let the villagers use this to build bridges, mutuality, reciprocity, respect and love across national boundaries. The fact that the US is being forced back into the world community rather than seeing itself standing over it has to be a good thing. We villagers must develop institutions that more accurately reflect our world values but it would seem that nothing less than a major revision of modern capitalism is now needed to promote anew the health and happiness of the world community and especially those in developing countries. There remains the horrible feeling however, as the US prepares to wage war not to solve the problem of terrorism but to make themselves feel better by "doing something", that it is already too late.

Curtin University, Perth WA 6845, Australia

GAVIN MOONEY

\title{
A new international public health target
}

The tragedy of New York, Washington, and Pittsburgh is both immediate and long term. Immediate in its violent loss and bereavement; the anger, anguish and personal "what ifs" that will devastate psychological wellbeing over the next few weeks and months. What if she/he had missed the train, woke up late, been on a lower floor, not gone back to their desk, not taken that plane, had a few more seconds...? I breathed a huge sigh of relief at news that my brother and his family who live in NY city were all safe. Not so for so many others.

The longer term effects will be more subtle and harder to both express and manage. I am an American living abroad, was an early teenager during the Cuban missile crisis. In talking with my 13 year old son, I suddenly and very uncomfortably remembered what it felt like at 13 to be afraid of death. A death coming I knew not when nor where. It would come loudly and violently as a bomb. It might hurt, I might not be with family or friends and may not be able to say goodbye. I had recurrent nightmares, lived with anxiety although at 13 I could not name what I felt. And now, he is doing the same.

In Afghanistan people live daily with an equal loss, though arguably less sudden and violent. Their children and family members die each day from starvation and disease. Which is worse and more damaging to watch and experience? How could one answer such a question? Their life expectancy is well below that of America. They unfortunately live all too frequently with anxiety of loss and war. It is human to feel envy and hatred of those that have when you have not. In society people respond differently and so it is with the Middle Eastern societies where the perceived injustices have festered and grown and now spill over.

A public health consideration may need to step out of the comfort zone and challenge some of the prevailing national and party political issues. How do we encourage and develop good psychological health, particularly in our children and young people, if they live in fear and learn to respond to fear and anxiety with aggression? How do we also encourage good psychological health in nation states? The fear is different, American and English children fearful of their overall safety, anxious about war, loss, and death. Afghan children fearful of hunger, cold, repression, disease, and death. Causes of fear may differ; outcomes are all too often similar. Is this a public health issue? I believe it is.

Having lived through the Cuban missile crisis I then spent my later teenager and early adult years living with the Vietnam war. My brother was 15, not much older than my son is and the same age as my nephew, at the time Americans began to fight in Vietnam; and 23 when he died there. I watched a bit of my mother die with him; and, a bit of my other brothers and me changed irrevocably. I vowed never to experience that; no son of mine would be sacrificed to war.

Now I have a son and my fear and anxiety are high; so are his. So presumably are many peoples in many countries.

I am angry with whoever actively or passively authorised the USA assault. They (individually and collectively) need to be confronted with the results of their actions. I want to shake them, shout at them, rant and rave at them. And I also want to ask them what has happened in their lives that has caused them to hate so much, that has led them to commit this act. I want to ask myself, as an American and I want America however painful to ask what could we have done differently? How might this have been avoided? And then we all need to act. I hope, at the moment seemingly against hope, that the action will not be about blanket aggression. Is this selfishly motivated, a mother trying to look after her son, protect his future? Possibly. And my instinct tells me that I share this feeling with many Afghan, Palestinian, Israeli, Arab, American, and English mothers. A desire to grow physically and psychologically healthy children - to see them live in peace and well being. Surely this must be one of our most pressing international public health targets?

ANDREA CAMPBELL

Sefton Health Authority, Waterloo, Merseyside, UK;

Andrea.Campbell@sefton-ha.nhs.uk

24 September 2001 